ES/ER/TM-78

\title{
Methodology for Estimating Radiation Dose Rates to Freshwater Biota Exposed to Radionuclides in the Environment
}

\author{
B. G. Blaylock \\ M. L. Frank \\ B. R. O'Neal
}


This report has been reproduced directly from the best available copy.

Available to DOE and DOE contractors from the Office of Scientific and Technical Information, P.O. Box 62, Oak Ridge, TN 37831; prices available from 423-576-8401 (fax 423-576-2865).

Available to the public from the National Technical Information Service, U.S. Department of Commerce, 5285 Port Royal Rd., Springfield, VA 22161. 
ES/ER/TM-78

\title{
Methodology for Estimating Radiation Dose Rates to Freshwater Biota Exposed to Radionuclides in the Environment
}

\author{
B. G. Blaylock \\ M. L. Frank \\ B. R. O’Neal
}

Date Issued-September 1993

\author{
Prepared for the \\ U.S. Department of Energy \\ Office of Environmental Management \\ under budget and reporting code EW 20 \\ LOCKHEED MARTIN ENERGY SYSTEMS, INC. \\ managing the \\ Environmental Management Activities at the \\ Oak Ridge K-25 Site Paducah Gaseous Diffusion Plant \\ Oak Ridge Y-12 Plant Portsmouth Gaseous Diffusion Plant \\ Oak Ridge National Laboratory \\ under contract DE-AC05-84OR21400 \\ for the \\ U.S. DEPARTMENT OF ENERGY
}


Page

EXECUTIVE SUMMARY $\ldots \ldots \ldots \ldots \ldots \ldots \ldots \ldots \ldots \ldots \ldots \ldots \ldots$ vii

1. INTRODUCTION $\ldots \ldots \ldots \ldots \ldots \ldots \ldots \ldots \ldots \ldots \ldots \ldots \ldots$

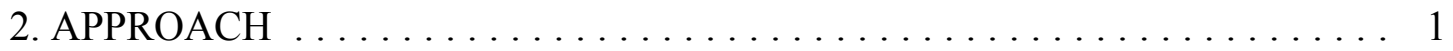

3. EFFECTS OF RADIATION ON AQUATIC ORGANISMS $\ldots \ldots \ldots \ldots \ldots 2$

4. RADIATION DOSE TO BIOTA $\ldots \ldots \ldots \ldots \ldots \ldots \ldots \ldots \ldots \ldots \ldots$

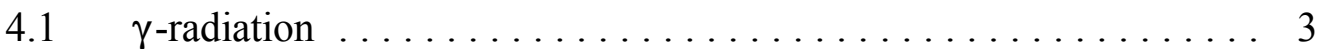

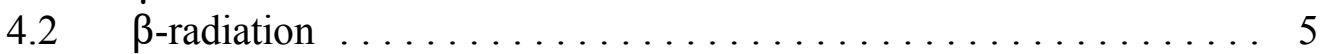

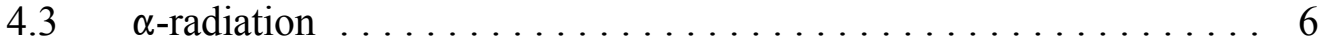

5. DOSE RATE CALCULATIONS FOR FISH EGGS $\ldots \ldots \ldots \ldots \ldots \ldots \ldots$

6. DOSE CALCULATIONS AND EFFECTS $\ldots \ldots \ldots \ldots \ldots \ldots \ldots$

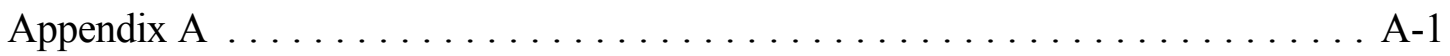

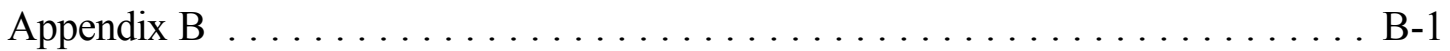




\section{EXECUTIVE SUMMARY}

The purpose of this report is to present a methodology for evaluating the potential for aquatic biota to incur effects from exposure to chronic low-level radiation in the environment. Aquatic organisms inhabiting an environment contaminated with radioactivity receive external radiation from radionuclides in water, sediment, and from other biota such as vegetation. Aquatic organisms receive internal radiation from radionuclides ingested via food and water and, in some cases, from radionuclides absorbed through the skin and respiratory organs. Dose rate equations, which have been developed previously, are presented for estimating the radiation dose rate to representative aquatic organisms from alpha, beta, and gamma irradiation from external and internal sources. Tables containing parameter values for calculating radiation doses from selected alpha, beta, and gamma emitters are presented in the appendix to facilitate dose rate calculations.

The risk of detrimental effects to aquatic biota from radiation exposure is evaluated by comparing the calculated radiation dose rate to biota to the U.S. Department of Energy's (DOE's) recommended dose rate limit of $0.4 \mathrm{mGy} \mathrm{h}^{-1}\left(1 \mathrm{rad} \mathrm{d}^{-1}\right)$. A dose rate no greater than $0.4 \mathrm{mGy} \mathrm{h}^{-1}$ to the most sensitive organisms should ensure the protection of populations of aquatic organisms. DOE's recommended dose rate is based on a number of published reviews on the effects of radiation on aquatic organisms that are summarized in the National Council on Radiation Protection and Measurements Report No. 109 (NCRP 1991). The literature identifies the developing eggs and young of some species of teleost fish as the most radiosensitive organisms. DOE recommends that if the results of radiological models or dosimetric measurements indicate that a radiation dose rate of $0.1 \mathrm{mGy} \mathrm{h}^{-1}$ will be exceeded, then a more detailed evaluation of the potential ecological consequences of radiation exposure to endemic populations should be conducted.

Dose rates have been calculated for biota in aquatic ecosystems associated with three national laboratories and one uranium mining and milling facility (NCRP 1991). At all sites, the dose rates were two orders of magnitude less than the value recommended by DOE for the protection of populations of aquatic biota. Therefore, it is highly unlikely that aquatic organisms will encounter dose rates in aquatic ecosystems that will be detrimental at the population level other than in man-made bodies of water associated with waste management activities or from accidental releases of radionuclides. 


\section{INTRODUCTION}

Sources of radioactivity in the aquatic environment include naturally occurring radionuclides, fallout from the atmospheric, runoff from watersheds that have received atmospheric deposition, and radioactive effluents from medical, industrial, and nuclear facilities released either accidentally or routinely. Depending upon the element and the chemical form, radionuclides may accumulate in bottom sediment or remain in the water column in the dissolved state. From either location, they can subsequently accumulate in biota and be transferred through the aquatic food chain. Contamination of the environment by radionuclides inevitably results in an increase in the radiation exposure of natural populations of organisms that occupy the contaminated area. Aquatic organisms receive external radiation exposure from radionuclides in water, sediment, and from other biota such as vegetation. They also receive internal radiation exposure from radionuclides ingested via food and water and from radionuclides absorbed through the skin and respiratory organs.

Generally, the discharge of radioactive waste into the environment is such that it results in only long-term, low-dose-rate exposure of organisms. In most cases, acute mortality can be discounted. The very small increase in morbidity and mortality that is contributed by an increased exposure to chronic irradiation is unlikely to be detectable because of the natural fluctuations in the sizes of populations of organisms in the aquatic environment. The purpose of this report is to present a methodology for evaluating the ecological risk to aquatic organisms that are exposed to anthropogenic radionuclides released into the environment.

\section{APPROACH}

Ecological risk to aquatic organisms exposed to radiation from anthropogenic radionuclides in the environment will be assessed by 1) calculating the dose to the organism and 2) comparing that dose to levels of radiation below which no detectable effects have been observed. Special consideration will be given to effects on reproductive parameters such as fecundity and embryo viability which would be the most likely to be adversely affected by exposure to radiation.

Although most radiation effect studies have evaluated effects at the organism level, assessments of ecological risk are usually concerned with the viability and success of populations. Unlike the case for humans in which malignancies and genetic abnormalities can be a personal catastrophe, there usually is not a similar concern about the survival of individual organisms in nature. An exception exists for threatened or endangered species or species with low fecundity (typically uncommon in freshwater ecosystems), where the survival of an individual could influence the success of the population. In most cases, the potential for over-reproduction of aquatic organisms is large and most individuals either become part of the natural food chain to be consumed by other organisms or starve. Therefore, for aquatic organisms there is little concern about small increases in the frequency of malignancies or genetic abnormalities because the weakest individuals are usually eliminated first in the natural selection process. 


\section{EFFECTS OF RADIATION ON AQUATIC ORGANISMS}

A large body of literature exists on the effects of radiation on aquatic organisms and has been reviewed extensively by a number of authors (IAEA 1976; Blaylock and Trabalka 1978; NRCC 1983; Egami and Ijiri 1979; Woodhead 1984; Anderson and Harrison 1986; NCRP 1991). The general consensus of the reviewers is that the most sensitive aquatic organisms known are teleost fish, particularly the developing eggs and young of some species. Additionally, the reviewers point out that most radiation effects studies have been conducted using acute exposures of radiation and less than $10 \%$ of the studies involved chronic or continuous irradiation. Because most environmental exposures are long-term, low-dose-rate exposures, data from chronic irradiation effect studies on the life cycle of organisms are the most useful in assessing the ecological risk to biota.

One approach that is used in assessing the risk of adverse ecological effects is to select indicator species of organisms for study. Indicator species are usually biologically significant organisms and are representative of the particular environment under investigation. An assessment of the environment will usually allow the identification of a few critical species of organisms for which dose estimates should be made. These species should provide adequate data for an assessment of effects from the radiation exposure to the community.

\section{RADIATION DOSE TO BIOTA}

Three approaches have been employed for calculating radiation doses to aquatic biota. Results of using these three approaches were evaluated by Woodhead (NCRP 1991). CRITR, a set of models and associated computer codes, was developed by Soldat et al. (1974) and recently revised by Baker and Soldat (1992) for application to discharges of effluents into surface waters. A simplified means was provided for calculating the concentrations of radionuclides in water, sediment, and two groups of organisms using a restricted number of parameters relating to the discharge source and the receiving water body.

A second approach involved two models, EXREM III and BIORAD (Trubey and Kaye 1973), which were developed from the starting point of a unit concentration of a radionuclide in water from which the concentration in an organism is determined by the application of a concentration factor. No means are given for estimating the concentration of a radionuclide in sediment or determining the exposure from contaminated sediment which may be significant.

A third approach, "Point Source Dose Distribution" (IAEA 1976, 1979), is advantageous in that it can be applied to any combination of radiation sources and target geometries. For any extended (nonpoint) source of ionizing radiation, the dose rate at a specified point can be obtained by the integration of an appropriate point source dose function over the source geometry. Although it is possible to derive theoretical expressions from first principles, these calculations are frequently complex due to the multiplicity of absorption and scattering phenomena which must be considered. For ease of computation, simple empirical expressions have been described for calculating doses to aquatic biota (IAEA 1976, 1979). 
Several factors makes estimating the radiation dose to an organism difficult. Different radionuclides are differentially distributed among the organs and tissues of an organism, affecting the radiation dose that sensitive organs and tissues receive. In addition, the relative significance of internal and external sources of radiation to an organism can be markedly altered by the size and behavior of the organism.

Radiation exposure models have been developed that incorporate parameters accounting for differences in the size and shape of an organism. The "Point Source Dose Distribution" methodology provides a means for calculating the radiation dose to different size categories of aquatic organisms using simplified equations. Measurements used to represent different size categories for a select group of aquatic organisms are given in Table 1.

\section{Table 1. Dimensions of organisms representing different size categories used in the Point Source Dose Distribution methodology for estimating radiation doses}

\begin{tabular}{|c|c|c|}
\hline Organism & $\begin{array}{c}\text { Mass } \\
(\mathrm{kg})\end{array}$ & $\begin{array}{l}\text { Length of the major } \\
\text { axes of the ellipsoid }\end{array}$ \\
\hline rgamsm & & \\
\hline
\end{tabular}

Small insects

and larvae

$1.6 \times 10^{-5}$

$0.62 \times 0.31 \times .0 .16$

Large insects

and molluscs

$1.0 \times 10^{-3}$

$2.5 \times 1.2 \times 0.62$

Small fish

$2.0 \times 10^{-3}$

$3.1 \times 1.6 \times 0.78$

Large fish

1.0

$45 \times 8.7 \times 4.9$

\section{1 $\gamma$-radiation}

For large organisms with dimensions greater than a few $\mathrm{cm}$, energy absorption and scattering become significant; therefore, a factor must be applied to account for these processes. Monte Carlo calculations have been made to include absorption and scattering for a number of geometries, and these calculations can be adapted for aquatic organisms (Brownell et al. 1968, Ellett and Humes 1971). The results are given in terms of the absorbed fraction which is defined as:

$$
\Phi=\frac{\text { photon energy absorbed by target }}{\text { photon energy emitted by source }}
$$


Absorbed fractions $(\Phi)$ which have been derived for the biota listed in Table 1 as a function of $\gamma$-ray energies (ICRP 1991) are given in Figures A.1 through A.3.

The $\gamma$-radiation dose rate from internal contamination is expressed as:

$$
\mathrm{D}_{\gamma}=5.76 \times 10^{-4} \mathrm{E}_{\gamma} \mathrm{n}_{\gamma} \Phi \mathrm{C}_{\mathrm{o}} \quad \mu \mathrm{Gy} \mathrm{h}^{-1} \quad \text { (1) }
$$

where

$\mathrm{E}_{\gamma} \quad$ is the photon energy emitted during transition from a higher to a lower energy state $(\mathrm{MeV})$

$\mathrm{n}_{\gamma} \quad$ is the proportion of disintegrations producing a $\gamma$-ray

$\Phi \quad$ is the absorbed fraction from Figures A.1 through A.3 of energy $E_{\gamma}(\mathrm{MeV})$ (dimensionless)

$\mathrm{C}_{\mathrm{o}} \quad$ is the concentration of the radionuclide in the organism (Bq kg ${ }^{-1}$ wet weight)

If a $\gamma$-emitter produces photons of different energy levels, the doses from all major $\gamma$-emissions should be included in the dose rate calculation.

It follows that the $\gamma$-radiation dose rate to the organism from radionuclides in water away from the sediment is

$$
\mathrm{D}_{\gamma}=5.76 \times 10^{-4} \mathrm{E}_{\gamma} \mathrm{n}_{\gamma}(1-\Phi) \mathrm{C}_{\mathrm{w}} \quad \mu \mathrm{Gy} \mathrm{h}^{-1}
$$

where

$\mathrm{C}_{\mathrm{w}}$ is the concentration of the radionuclide in water $(\mathrm{Bq} \mathrm{L})$

The $\gamma$-radiation dose rate to organisms at the sediment-water interface from a uniformly contaminated sediment is

$$
\mathrm{D}_{\gamma}=2.88 \times 10^{-4} \mathrm{E}_{\gamma} \mathrm{n}_{\gamma}(1-\Phi) \mathrm{C}_{\mathrm{s}} \mathrm{R} \quad \mu \mathrm{Gy} \mathrm{h} \mathrm{h}^{-1}
$$

where

$\mathrm{C}_{\mathrm{s}} \quad$ is the concentration of the radionuclide in sediment $\left(\mathrm{Bq} \mathrm{kg}{ }^{-1}\right.$ wet weight). A generic value of 0.75 can be used for converting sediment from dry weight to wet weight.

$\mathrm{R} \quad$ is the fraction of time that the organism spends at the sediment-water interface.

Because of deposition and resuspension of sediment, decay of the radioisotope, and the variability in the rate at which a radionuclide may be released into a aquatic system, sediment rarely presents a uniform, semi-infinite source of $\gamma$-radiation. Therefore, in most cases, equation (3) will over estimate the dose to biota at the sediment-surface water interface. In those cases where detailed information is not available, 0.5 times the $\mathrm{D}_{\gamma}$ in equation (3) can be used to account for the unequal distribution of radionuclides in the sediment (IAEA 1976, Woodhead 1984). 
Table A.1 contains the average energy per transformation for a selected group of gamma emitters. These values were taken from ICRP Report 38 (1983) and can be used in place of $\mathrm{E}_{\gamma}$ and $\mathrm{n}_{\gamma}$ in the preceding equations to calculate the total $\gamma$-radiation dose rate in one step. Examples illustrating the calculation of $\gamma$-radiation dose rates are given in Appendix B.

\section{2 $\quad \beta$-radiation}

The point source $\beta$-dose function (NCRP 1991, Woodhead 1979) was integrated over the geometries given in Table 1, assuming a uniform distribution of the radionuclide in the organism, to obtain the dose rate at the center of the organism as a fraction of the total $\beta$-dose rate. The results are shown in Fig. A.4 as a function of maximum $\beta$-particle energy for the three small geometries. For large fish and turtles, the internal $\beta$-dose rate is independent of the $\beta$-particle energy; therefore,

$$
\mathrm{D}_{\beta}=5.76 \times 10^{-4} \overline{\mathrm{E}}_{\beta} \mathrm{n}_{\beta} \mathrm{C}_{\mathrm{o}} \quad \mu \mathrm{Gy} \mathrm{h}^{-1}
$$

The internal $\beta$-radiation dose rate for the three small geometries is given by the following equation

where

$$
\mathrm{D}_{\beta}=5.76 \times 10^{-4} \overline{\mathrm{E}}_{\beta} \mathrm{n}_{\beta} \Phi \mathrm{C}_{\mathrm{o}} \quad \mu \mathrm{Gy} \mathrm{h}^{-1}
$$

$\overline{\mathrm{E}}_{\beta} \quad$ is the average energy of the $\beta$-particle $(\mathrm{MeV})$

$\mathrm{n}_{\beta} \quad$ is the proportion of transitions producing a $\beta$-particle of energy $\mathrm{E}_{\beta}(\mathrm{MeV})$ (dimensionless)

$\Phi \quad$ is the absorbed fraction from Fig. A.4

$\mathrm{C}_{\mathrm{o}} \quad$ is the concentration of the radionuclide in the organism ( $\mathrm{Bq} \mathrm{kg}{ }^{-1}$ wet weight)

It is assumed that $\beta$-radiation from water contributes a negligible amount to the internal dose rate of large fish and turtles. The external $\beta$-dose rate from water for the smaller organisms described in Table 1 is

where

$$
\mathrm{D}_{\beta}=5.76 \times 10^{-4} \overline{\mathrm{E}}_{\beta} \mathrm{n}_{\beta}(1-\Phi) \mathrm{C}_{\mathrm{w}} \quad \mu \mathrm{Gy} \mathrm{h} \mathrm{h}^{-1} .
$$

$\mathrm{C}_{\mathrm{w}}$ is the concentration of the radionuclide in water $(\mathrm{Bq} \mathrm{L})$

The external $\beta$-dose rate from sediment for organisms represented by the three small geometries that are in contact with the sediment surface is

where

$$
\mathrm{D}_{\beta}=2.88 \times 10^{-4} \overline{\mathrm{E}}_{\beta} \mathrm{n}_{\beta}(1-\Phi) \mathrm{C}_{\mathrm{s}} \mathrm{R} \quad \mu \mathrm{Gy} \mathrm{h} \mathrm{h}^{-1} .
$$

$\mathrm{C}_{\mathrm{s}} \quad$ is the concentration of the radionuclide in sediment ( $\mathrm{Bq} \mathrm{kg} \mathrm{kg}^{-1}$ wet weight). A generic value of 0.75 can be used for converting sediment from dry weight to wet weight.

$\mathrm{R}$ is the fraction of time that the organism spends at the sediment-water interface. 
Some aquatic organisms may be surrounded by sediment during certain life stages and, in such cases, $5.76 \times 10^{-4}$ instead of $2.88 \times 10^{-4}$ would be the appropriate unit conversion factor.

Beta emitters that decay by alternative transitions produce an energy spectrum for each mode of transition. The dose rates from the major spectra must be included when calculating the total $\beta$-dose rate to an organism. Table A.1 contains a list of the maximum and average energies of selected $\beta$-emitters based on $\beta$-particles, conversion electrons, and Auger radiations. These values were obtained from ICRP Report 38 (1983). Examples demonstrating the use of the data in Table A.1 to calculate $\beta$-dose rates are given in Appendix B.

\section{3 $\alpha$-radiation}

For organisms of the sizes represented in Table 1, the internal dose rate from $\alpha$-radiation closely approaches the dose rate from an infinite source because essentially all the energy from $\alpha$-particles is absorbed within the organism. The internal dose rate from $\alpha$-radiation is calculated as follows:

$$
\mathrm{D}_{\alpha}=5.76 \times 10^{-4} \mathrm{E}_{\alpha} \mathrm{n}_{\alpha} \mathrm{C}_{\mathrm{o}} \quad \mu \mathrm{Gy} \mathrm{h}^{-1}
$$

where

$\mathrm{E}_{\alpha} \quad$ is the energy of the $\alpha$-particle $(\mathrm{MeV})$

$\mathrm{n}_{\alpha} \quad$ is the proportion of transitions producing an $\alpha$-particle of energy $\mathrm{E}_{\alpha}(\mathrm{MeV})$ (dimensionless)

$\mathrm{C}_{\mathrm{o}} \quad$ is the concentration of the radionuclide in the organism (Bq kg-1 wet weight)

If $\alpha$-particles of more than one energy level are produced during the decay of a radioisotope, the dose rate from all transitions are summed to obtain the total a-dose rate. It is assumed that external $\alpha$-radiation from water and sediment is insignificant for organisms of the sizes shown in Table 1.

Table A.2 gives the average $\alpha$-energies for selected $\alpha$-emitters including those in naturally occurring $\alpha$-decay chains. The average energy of $\beta$ - and $\gamma$-emissions produced by the $\alpha$-decay are also given. Examples illustrating the calculation of dose rates for a-emitters are presented in Appendix B.

The dose rates in this report are expressed in units of absorbed dose ( $\mu \mathrm{Gy})$; however, different types of radiations differ in their relative biological effectiveness per unit of absorbed dose. A quality factor, Q, is normally used to account for the difference in biological effectiveness of the different radiations (NCRP 1987). Quality factors have been derived from data on humans and are intended to be used only for low doses, not high doses that might result from a nuclear accident. A quality factor of 1 is used for $\mathrm{x}^{-}$, $\gamma$-, and $\beta$-radiation and 20 for $\alpha$-radiation. Therefore, to equate the relative biological effectiveness of the dose rate from $\alpha$-radiation in $\mu \mathrm{Gy}$ to the rate from $\gamma$ - and $\beta$ - 
radiations, the $\alpha$-dose rate should be multiplied by 20 . In effect, the resulting dose rate would be equivalent to microsieverts $(\mu \mathrm{Sv})$, the dose equivalent unit used for humans.

\section{DOSE RATE CALCULATIONS FOR FISH EGGS}

The calculation of a radiation dose to fish eggs/embryos exposed to radionuclides in the environment is a complex procedure that requires answers to a number of questions. These questions include: Is the radionuclide inside the egg or is it adsorbed to the outer shell or chorion? If the radionuclide is inside the egg, is it uniformly distributed? What is the diameter of the egg? Where is the developing embryo located? Do the eggs float, sink to the bottom, form clusters, adhere to vegetation or other objects, etc.? How long is the development period and does the radionuclide concentration change with time? If answers to these questions are available, it is possible to use mathematical models for different geometries and physical conditions to calculate the radiation dose rate to fish eggs/embryos (Adams 1968, Woodhead 1970, Ellett and Humes 1971, IAEA 1979). However, for most purposes a conservative estimate of the radiation dose rate is sufficient. The following discussion presents a simplified approach for estimating the dose rate to fish eggs/embryos from radionuclides in the environment.

\section{$\gamma$-radiation to Fish Eggs}

Most fish eggs are only a few millimeters in diameter; therefore, the radiation dose rate from internal $\gamma$-emitters would be insignificant (Ellett and Humes 1971, IAEA 1976). The external dose rate to an egg from $\gamma$-emitters in the surrounding water would be the average dose rate in an effectively infinite source (i.e., the dimensions of the source are much greater than the attenuation length of the radiation). The unit density of the fish eggs and the source (water) are assumed to be the same. The equation for the $\gamma$ dose rate from an infinite source is

where

$$
\mathrm{D}_{\gamma}(\infty)=5.76 \times 10^{-4} \mathrm{E}_{\gamma} \mathrm{n}_{\gamma} \mathrm{C}_{\mathrm{w}} \quad \mu \mathrm{Gy} \mathrm{h}^{-1}(9)
$$

$\mathrm{E}_{\gamma} \quad$ is the photon energy emitted during transition from a higher to a lower energy state $(\mathrm{MeV})$

$\mathrm{n}_{\gamma} \quad$ is the proportion of disintegrations producing a $\gamma$-ray of energy $\mathrm{E}_{\gamma}(\mathrm{MeV})$ (dimensionless)

$\mathrm{C}_{\mathrm{w}} \quad$ is the concentration of the radionuclide in water $\left(\mathrm{Bq} \mathrm{L}^{-1}\right)$

Because the activity of most radionuclides in water is much lower than in biological tissue and because eggs of most species of freshwater fish hatch in a few weeks or less, it is unlikely that the radiation dose from $\gamma$-emitters in the environment would have a deleterious effect on fish eggs/embryos.

Fish eggs may receive external $\gamma$-radiation from other sources such as sediment and vegetation and a number of geometric factors would affect the dose rate. For most radionuclides, the activity in the sediment is much higher than in the water, so that the dose rate from the sediment will be higher than from the water. However, the dose rate 
to fish eggs would depend upon the photon energy and their distance from the sediment surface. Assuming that the sediment is a uniformly contaminated slab source of infinite area and the eggs are lying on the sediment surface, the following equation can be used to estimate the $\gamma$-dose rate to the eggs.

$$
\mathrm{D}_{\gamma}(\infty)=2.88 \times 10^{-4} \mathrm{E}_{\gamma} \mathrm{n}_{\gamma} \mathrm{C}_{\mathrm{s}} \quad \mu \mathrm{Gy} \mathrm{h} \mathrm{h}^{-1}
$$

where

$\mathrm{E}_{\gamma} \quad$ is the photon energy emitted during transition from a higher to a lower energy state $(\mathrm{MeV})$

$\mathrm{n}_{\gamma} \quad$ is the proportion of disintegrations producing a $\gamma$-ray of energy $\mathrm{E}_{\gamma}(\mathrm{MeV})$ (dimensionless)

$\mathrm{C}_{\mathrm{s}} \quad$ is the concentration of the radionuclide in sediment $\left(\mathrm{Bq} \mathrm{kg}{ }^{-1}\right.$ wet weight $)$. A generic value of 0.75 can be used for converting sediment from dry weight to wet weight.

\section{$\beta$-radiation to Fish Eggs}

Equations for calculating the dose rate to fish eggs from internal $\beta$-emitters are complex and beyond the scope of this report. By assuming that all the energy from internal $\beta$-emitters is absorbed within the egg, the following equation can be used to estimate the dose.

where

$$
\mathrm{D}_{\beta}=5.76 \times 10^{-4} \overline{\mathrm{E}}_{\beta} \mathrm{n}_{\beta} \mathrm{C}_{\mathrm{o}} \quad \mu \mathrm{Gy} \mathrm{h}^{-1}
$$

$\overline{\mathrm{E}}_{\beta} \quad$ is the average energy of the $\beta$-particle $(\mathrm{MeV})$

$n_{\beta} \quad$ is the proportion of transitions producing a $\beta$-particle of energy $\bar{E}_{\beta}(\mathrm{MeV})$ (dimensionless)

$\mathrm{C}_{\mathrm{o}} \quad$ is the concentration of the radionuclide in the organism $\left(\mathrm{Bq} \mathrm{kg}^{-1}\right.$ wet weight $)$

Results of equation (11) are approximately true for low-energy $\beta$-radiation; however, as the $\beta$-particle energy increases, the extent of over estimation increases. If the estimated dose rate indicates that harmful effects might occur, then a more accurate dose rate should be determined. Equations for calculating dose rates to fish eggs are available in the literature (IAEA 1979, Adams 1968, and Woodhead 1970).

If the range of the $\beta$-radiation in the surrounding water exceeds the radius of the eggs, then the dose rate to the eggs from the water is

$$
\mathrm{D}_{\beta}=5.76 \times 10^{-4} \overline{\mathrm{E}}_{\beta} \mathrm{n}_{\beta} \mathrm{C}_{\mathrm{w}} \quad \mu \mathrm{Gy} \mathrm{h}^{-1}
$$

where

$\overline{\mathrm{E}}_{\beta} \quad$ is the average energy of the $\beta$-particle $(\mathrm{MeV})$

$n_{\beta} \quad$ is the proportion of transitions producing a $\beta$-particle of energy $\bar{E}_{\beta}(\mathrm{MeV})$ (dimensionless)

$\mathrm{C}_{\mathrm{w}} \quad$ is the concentration of the radionuclide in water $\left(\mathrm{Bq} \mathrm{L} \mathrm{L}^{-1}\right)$ 
Equation (12) can be used to estimate the $\beta$-dose rate from water in instances where the range of the $\beta$-particle is less than the radius of the egg but the dose rate will be over estimated. As mentioned above, if the estimated dose rate indicates harmful effects might occur, then a more accurate estimate of the dose rate should be obtained.

Fish eggs can also receive $\beta$-radiation from contact with surfaces such as sediment or vegetation. The dose rate will depend upon the thickness and density of the material as well as the energy of the $\beta$-radiation. The following equation can be used to estimate to dose to eggs that are in contact with sediment although in most situations it will over estimate the dose rate.

where

$$
\mathrm{D}_{\beta}=2.88 \times 10^{-4} \overline{\mathrm{E}}_{\beta} \mathrm{n}_{\beta} \mathrm{C}_{\mathrm{s}} \mathrm{R} \quad \mu \mathrm{Gy} \mathrm{h}^{-1} .
$$

$\mathrm{C}_{\mathrm{s}} \quad$ is the concentration of the radionuclide in sediment $\left(\mathrm{Bq} \mathrm{kg}{ }^{-1}\right.$ wet weight). A generic value of 0.75 can be used for converting sediment from dry weight to wet weight

$\mathrm{R} \quad$ is the fraction of time that the organism spends at the sediment-water interface.

\section{$\alpha$-radiation to Fish Eggs}

Assuming that all the radiation from internal $\alpha$-emitters remains within the egg and that all external $\alpha$-radiation is stopped by the chorion, a reasonable estimate of the dose rate from $\alpha$-emitters is given by

$$
\mathrm{D}_{\alpha}=5.76 \times 10^{-4} \mathrm{E}_{\alpha} \mathrm{n}_{\alpha} \mathrm{C}_{\mathrm{o}} \quad \mu \mathrm{Gy} \mathrm{h}^{-1}
$$

where

$\mathrm{E}_{\alpha} \quad$ is the energy of the $\alpha$-particle $(\mathrm{MeV})$

$\mathrm{n}_{\alpha} \quad$ is the proportion of transitions producing an $\alpha$-particle of energy $\mathrm{E}_{\alpha}(\mathrm{MeV})$ (dimensionless)

$\mathrm{C}_{\mathrm{o}} \quad$ is the concentration of the radionuclide in the organism $\left(\mathrm{Bq} \mathrm{kg}^{-1}\right.$ wet weight)

\section{DOSE CALCULATIONS AND EFFECTS}

The previously listed equations can be used to calculate a dose rate to aquatic biota for most situations. Bioaccumulation factors for freshwater fish for selected radioisotopes are included in Tables A.1 and A.2. These factors can be used to estimate the concentration of a radioisotope in freshwater fish from the concentration in the surrounding water. Information on the decay schemes of additional radioisotopes can be obtained from ICRP 38 (ICRP 1983), Kocher (1981), and the Health Physics and Radiological Health Handbook (Shleien et al. 1984). Equations for calculating dose rates for other biota, such as fish eggs, phytoplankton, and zooplankton, can be found in IAEA Technical Reports Series No. 172 (1976) and Series No. 190 (1979). After determining 
the dose rate to an organism from each individual radioisotope in the environment, the total dose rate to the organism is determined by summing the dose rates (in dose equivalents) from all radioisotopes. The total dose rate can then be compared to literature values for radiation effects on the same or closely related organisms. The most appropriate values for comparison are those from chronic exposure studies conducted over the life cycle of an organism; however, it is often necessary to extrapolate the results of acute exposures to chronic exposures.

A number of reviews on the effects of radiation on aquatic organisms have been published over the last three decades (Polikarpov 1966, Templeton et al. 1971, Chipman 1972, IAEA 1976, Blaylock and Trabalka 1978, IAEA 1979, Egami 1980, NRCC 1983, Woodhead 1984, Anderson and Harrison 1986, NCRP 1991, and IAEA 1992). These reviews considered data from field and laboratory studies from both marine and freshwater environments. More data have been collected on marine than on freshwater species; however, where reasonable comparisons can be made, there is no evidence that significance differences in radiosensitivity exists between marine and freshwater organisms. NCRP Report No. 109 (NCRP 1991) contains summary tables of the effects of chronic irradiation on fish and invertebrates. Tables A.3 through A.6 are modifications of the NCRP tables. For information on specific organisms not contained in these tables, individual reviews can be consulted, for example, Woodhead (1984).

Methods for dose calculations for phytoplankton and zooplankton are not included in this document because these organisms are relatively resistant to irradiation exposure (Table A.5) (Marshall 1962, 1966). From reviews of the literature (IAEA 1976; Blaylock and Trabalka 1978; Woodhead 1984), detrimental effects on organisms of higher trophic levels should be detected before populations of phytoplankton and zooplankton are affected by exposure to radiation. Therefore, dose calculations for organisms of higher trophic levels are emphasized in this report. The methodology for calculating dose rates for phytoplankton and zooplankton is available in the IAEA Technical Report 172 (1976).

The U.S. Department of Energy's (DOE) guideline for radiation dose rates from environmental sources, which recommends limiting the radiation dose to aquatic biota to $0.4 \mathrm{mGy} \mathrm{h}^{-1}$ (1 $\mathrm{rad} \mathrm{day}^{-1}$ ), is based on results of previously cited reviews summarized in NCRP Report No. 109 (NCRP 1991). The conclusion from these reviews is that at 0.4 $\mathrm{mGy} \mathrm{h}{ }^{-1}$, there is no evidence that deleterious effects have been expressed at the population level for aquatic biota. Tables A.3 through A.5 contain summaries from the literature reviewed in NCRP Report No. 109 on reproductive effects in fish exposed to chronic irradiation. In these chronic irradiation studies, effects were not detected unless the dose rates were much greater than $0.4 \mathrm{mGy} \mathrm{h-}{ }^{1}$. However, populations may be at risk from other factors, such as over exploitation or other environmental stresses, which might in combination with radiation have an undesirable impact. Therefore, it is desirable to conduct a comprehensive ecological evaluation of the radiation exposure regime in combination with other environmental factors in order to assess the potential for radiation contributing to effects at the population level. It is recommended (NCRP 1991) that where the results of radiological models or dosimetric measurements indicate 
a dose rate of $0.1 \mathrm{mGy} \mathrm{h}^{-1}$ or more to aquatic biota, a more detailed evaluation of the ecological consequences to the endemic biota should be conducted.

According to the radiation effects literature, the most radiosensitive aquatic organisms are the developing eggs and young of some species of teleost fish. With few exceptions, the developmental period for freshwater fish eggs is relatively short but it can range from 3 days for the common carp Cyprinous carpio to more than 70 days for some salmonidae species. For this reason, the accumulated radiation dose to fish eggs from chronic environmental radiation should be relatively small. It is highly unlikely that dose rates in natural aquatic ecosystems that receive routine releases of radioactive effluents would produce effects on developing eggs and young of fish that would influence the success of the population. Exceptions to this premise could occur as a result of accidental releases of unacceptable levels of radioactive effluents or in man-made waste disposal ponds where high concentrations of radionuclides may be present.

In NCRP Report No. 109 (NCRP 1991), dose rates to aquatic organisms were calculated for three DOE-operated sites and one site in Canada: Gable Mountain Pond, Hanford Plant, Washington; White Oak Lake, Oak Ridge National Laboratory, Tennessee; Savannah River Plant, South Carolina; and Beaverlodge Uranium Mining Area, Saskatchewan, Canada. The estimated whole-body doses received by aquatic organisms at these sites were more than two orders of magnitude below the proposed standard of $0.4 \mathrm{mGy} \mathrm{h}^{-1}$. However, a few dose rates approached $0.1 \mathrm{mGy} \mathrm{h}^{-1}$, which might in combination with environmental stresses have an undesirable impact. The highest dose rates occurred in man-made ponds associated with waste management activities and these ponds have no direct connection with natural bodies of water. Remedial actions have been implemented at these sites. Therefore, it is highly unlikely that environmental situations will be encountered where the risk from radiation exposure from releases of radioactive waste to the environment would produce detrimental effects on aquatic organisms at the population level.

The methodology for calculating conservative (upper-limit) radiation dose rates provided in this document can be used to estimate dose rates to biota inhabiting aquatic environments contaminated with radionuclides. If the dose rate to aquatic organisms is less than the DOE's recommended level of $0.4 \mathrm{mGy} \mathrm{h}^{-1}\left(1 \mathrm{rad} \mathrm{day}^{-1}\right)$, there should be no detrimental effects from radiation exposure at the population level, i.e., there should be no quantifiable risk to the biota. If estimated dose rates exceed $0.1 \mathrm{mGy} \mathrm{h}^{-1}$, then studies should be implemented to determine whether effects can be detected at the individual and/or population level for biota inhabiting the environment. 


\section{REFERENCES}

Adams, N. 1968. Dose-rate distributions from spherical and spherical-shell radiation sources, with special reference to fish eggs in radioactive media. Authority Health and Safety Branch Report No. AHSB (RP) R 87, United Kingdom Atomic Energy Authority, Harwell, Didcot, Berkshire.

Anderson, S. L., and F. L. Harrison. 1986. Effects of Radiation on Aquatic Organisms and Radiobiological Methodologies for Effects Assessment. EPA Report No. 520/1-85016, United States Environmental Protection Agency, Washington, D.C.

Baker, D. A. and J. K. Soldat. 1992. Methods for Estimating Doses to Organisms from Radioactive Materials Released into the Aquatic Environment. PNL-8150, Battelle Pacific Northwest Laboratories, Richland, Washington.

Blaylock, B. G. 1969. "The fecundity of a Gambusia affinis affinis population exposed to chronic environmental radiation." Radiat. Res. 37:108-117.

Blaylock, B. G. and M. L. Frank. 1980. "Effects of chronic low-level irradiation on Gambusia affinis." p. 81-91. In: N. Egami (ed.), Radiation Effects on Aquatic Organisms. University Park Press, Baltimore, Maryland.

Blaylock, B. G. and J. R. Trabalka. 1978. "Evaluating the effects of ionizing radiation on aquatic organisms." 7:103-152. In: J. T. Lett and H. Alder (eds.), Advances in Radiation Biology. Academic Press, New York.

Bonham, K. and L. R. Donaldson. 1972. "Sex ratios and retardation of gonadal development in chronically gamma-irradiated chinook salmon smolts." Trans. Am. Fish. Soc. 101:428-434.

Brownell, G. L., W. H. Ellett and A. R. Reddy. 1968. "Absorbed fractions for photon dosimetry." J. Nuclear Medicine, Suppl 1, 27.

Chipman, W. A. 1972. "Ionizing Radiation." 1:1578. In: O. Kinne (ed.), Marine Ecology. John Wiley and Sons, Ltd. Chichester, U. K.

Cooley, J. L. 1973a. "Effects of temperature and chronic irradiation on natural populations of the aquatic snail (Physa heterostropha)." Radiat. Res. 54:130-140.

Cooley, J. L. 1973b. "Effects of temperature and chronic irradiation on natural populations of the aquatic snail (Physa heterostropha)." In: D. J. Nelson (ed.), Radionuclides in Ecosystems, CONF-710501-P1. 1:585-590. U. S. Atomic Energy Commission, Washington, D.C.

Cooley, J. L. and F. L. Miller Jr. 1971. "Effects of chronic irradiation on laboratory populations of the aquatic snail (Physa heterostropha)." Radiat. Res. 47:716-724 
Cosgrove, G. E. and B. G. Blaylock. 1973. "Acute and chronic irradiation effects in mosquitofish at 15 or $25^{\circ} \mathrm{C}$." In: D. J. Nelson (ed.), Radionuclides in Ecosystems, CONF-710501-P1. 1:579-584. U. S. Atomic Energy Commission, Washington, D.C.

Cosgrove, G. E., B. G. Blaylock, G. V. Ulriklson and P. H. Cohan. 1975. "Radiationinduced hematopoietic lesions in fish." In: W. E. Ribelin and G. Migaki (eds.), Pathology of Fishes. p. 463-476. University of Wisconsin Press, Madison.

Egami, N., Ed. 1980. Radiation effects on aquatic organisms. Proceedings of The International Symposium on Radiation Effects on Aquatic Organisms, Japan, 1979 (Japan Scientific Societies Press, Tokyo and University Park Press, Baltimore).

Egami, N. and K. Ijiri. 1979. "Effects of irradiation on germ cell and embryonic development in teleosts." Int. Rev. Cytol. 59:195-208.

Ellett, W. H. and R. M. Humes. 1971. "Absorbed fractions for small volumes containing photon-emitting radioactivity." J. Nuclear Medicine, Suppl. 5, 12:25 32.

Erickson, R. C. 1973. "Effects of chronic irradiation by tritiated water on Poecilias reticulata, the guppy." In: D. J. Nelson (ed.), Radionuclides in Ecosystems, CONF710501-P2. 2:1091-1099. U. S. Atomic Energy Commission, Washington, D.C.

Hyodo-Taguchi, Y. 1980. "Effects of chronic $\gamma$-irradiation on spermatogenesis in the fish, (Oryzias latipes), with special reference to regeneration of testicular stem cells." In: N. Egami (ed.) Radiation Effects on Aquatic Organisms. p. 91-104. University Park Press, Baltimore.

Hyodo-Taguchi, Y. and N. Egami. 1977. "Damage to spermatogenic cells in fish kept in tritiated water." Radiat. Res. 71:641-652.

IAEA (International Commission on Radiological Protection). 1976. Effects of Ionizing Radiation on Aquatic Organisms and Ecosystems. IAEA Technical Report Series 172. Vienna, Austria.

IAEA (International Commission on Radiological Protection). 1979. Methodology for Assessing Impacts of Radioactivity on Aquatic Ecosystems. IAEA Technical Report Series 190. Vienna, Austria.

IAEA (International Commission on Radiological Protection). 1992. Effects of Ionizing Radiation on Plants and Animals at Levels Implied by Current Radiation Protection Standards. IAEA Technical Report Series 332. Vienna, Austria.

ICRP (International Commission on Radiological Protection). 1983. Radionuclide Transformations: Energy and Intensity of Emissions. ICRP Publication No. 38. 
Kocher, D. C. 1981. Radioactive Decay Data Tables, A Handbook of Decay Data for Application to Radiation Dosimetry and Radiological Assessments. DOE/TIC-11026. Technical Information Center, U. S. Department of Energy, Oak Ridge, Tennessee.

Marshall, J. S. 1962. "The effect of continuous gamma-radiation on the intrinsic rate of natural increase of Daphnia pulex." Ecology. 43:598-607.

Marshall, J. S. 1966. "Population dynamics of Daphnia pulex as modified by chronic radiation stress." Ecology. 47:561-571.

NCRP (National Council on Radiation Protection and Measurements. 1991. Effects of Ionizing Radiation on Aquatic Organisms. NCRP Report No. 109, National Council on Radiation Protection and Measurements, Bethesda, Maryland.

NCRP (National Council on Radiation Protection and Measurements. 1987. Recommendations on Limits for Exposure to Ionizing Radiation. NCRP Report No. 91, National Council on Radiation Protection and Measurements, Bethesda, Maryland.

Newcombe, H. B. and J. F. McGregor. 1967. "Major congenital malformations from irradiations of sperm and eggs." Mutation Research. 4:663-673.

NRCC (National Research Council of Canada). 1983. Radioactivity in the Canadian Aquatic Environment. Public. No. NRCC-19250, National Radiation Council of Canada, Ottawa.

Peshkov, S. P., I. A. Shekhanova, G. N. Romanov, B. S. Prister and G. P. Sheyin. 1978. "Biological characteristics of roach (Rutilis rutilis lacustris Pall.) after living in water, containing ${ }^{90} \mathrm{Sr}$ and ${ }^{137} \mathrm{Cs} . "$ In: Radioecological Problems of Atomic Power Plant Cooling-Reservoirs. Urals Scientific Center, Academy of Sciences of the USSR, Sverdlovsk. (In Russian).

Polikarpov, G. G. 1966. Radioecology of Aquatic Organisms. Reinhold Book Division, New York.

Purdom, C. E. and D. S. Woodhead. 1973. "Radiation damage in fish." In: J. H. Schroeder (ed. ), Genetics and Mutagenesis of Fish. p. 67-73. Springer-Verlag, New York, NY.

Rackham, B. D. and D. S. Woodhead. 1984. "Effects of chronic gamma-radiation on the gonads of adult Ameca splendens (Osteichthyes: Teleostei)." Int. J. Radiat. Biol. 45:645-656.

Shleien, B. and M. S. Terpilak Eds. 1984. The Health Physics and Radiological Health Handbook. Nucleon Lectern Associates, Inc. 
Soldat, J. K., N. M. Robinson and D. A. Baker. 1974. Models and Computer Codes for Evaluating Environmental Radiation Doses, BNWL-1754, Battelle Pacific Northwest Laboratories, Richland, Washington.

Strand, J. A., M. P. Fujihara, W. L. Templeton, and E. G. Tangen. 1973. "Suppression of Chondrococcus columnaris immune response in rainbow trout sublethally exposed to tritiated water during embryogenesis." In: Radioactive Contamination of the Marine Environment, International Atomic Energy Agency, Vienna, p. 543-549.

Strand, J. A., W. L. Templeton, and E. G. Tangen. 1973. "Accumulation and retention of tritium (tritiated water) in embryonic and larval fish, and radiation effect." In: D. J. Nelson (ed.), Radionuclides in Ecosystems, CONF-710501-P1. 1:445-451. U. S. Atomic Energy Commission, Washington, D.C.

Templeton, W. L., R. E. Nakatani, and E. E. Held. 1971. Radiation Effects. Radioactivity in the Marine Environment. pp. 223-239. National Academy of Science, Washington DC.

Trabalka, J. R. and C. P. Allen. 1977. "Aspects of fitness of a mosquitofish Gambusia affinis exposed to chronic low-level environmental radiation." Radiat. Res. 70:198211.

Trubey, D. K. and S. V. Kaye. 1973. The EXREM III computer code for estimating external radiation doses to populations from environmental releases. ORNL-TM-4322. Oak Ridge National Laboratory, Oak Ridge, Tennessee.

Voronina, E. A., S. P. Peshkov and I. A. Shekhanova. 1974. The rate of growth and fecundity of fish living in a medium with a raised level of irradiation. Trudy Vses. Nauchno-Issled. Inst. Morsk. Rybn. Khoz. Okeanogr. 100:74-79. (In Russian).

Woodhead, D. S. 1970. "The assessment of the radiation dose to developing fish embryos due to the accumulation of radioactivity by the egg." Radiat. Res. 43:582-597. 
Woodhead, D. S. 1977. "The effects of chronic irradiation on the breeding performance of the guppy, (Poecilia reticulata) (Osteichthyes: Teleostei)." Int. J. Radiat. Biol. 32:122.

Woodhead, D. S. 1979. Methods of dosimetry for aquatic organisms, page 43 in Methodology for Assessing Impacts of Radioactivity on Aquatic Ecosystems, Tech. Rep. Ser. 190 (International Atomic Energy Agency, Vienna).

Woodhead, D. S. 1984. "Contamination due to Radioactive Materials." p. 1111-1287. In: O. Kinne (ed.), Marine Ecology, Vol. V, Part 3: Pollution and Protection of the SeasRadioactive Materials, Heavy Metals and Oil. John Wiley and Sons, New York, NY. 
Appendix A

FIGURES AND TABLES 


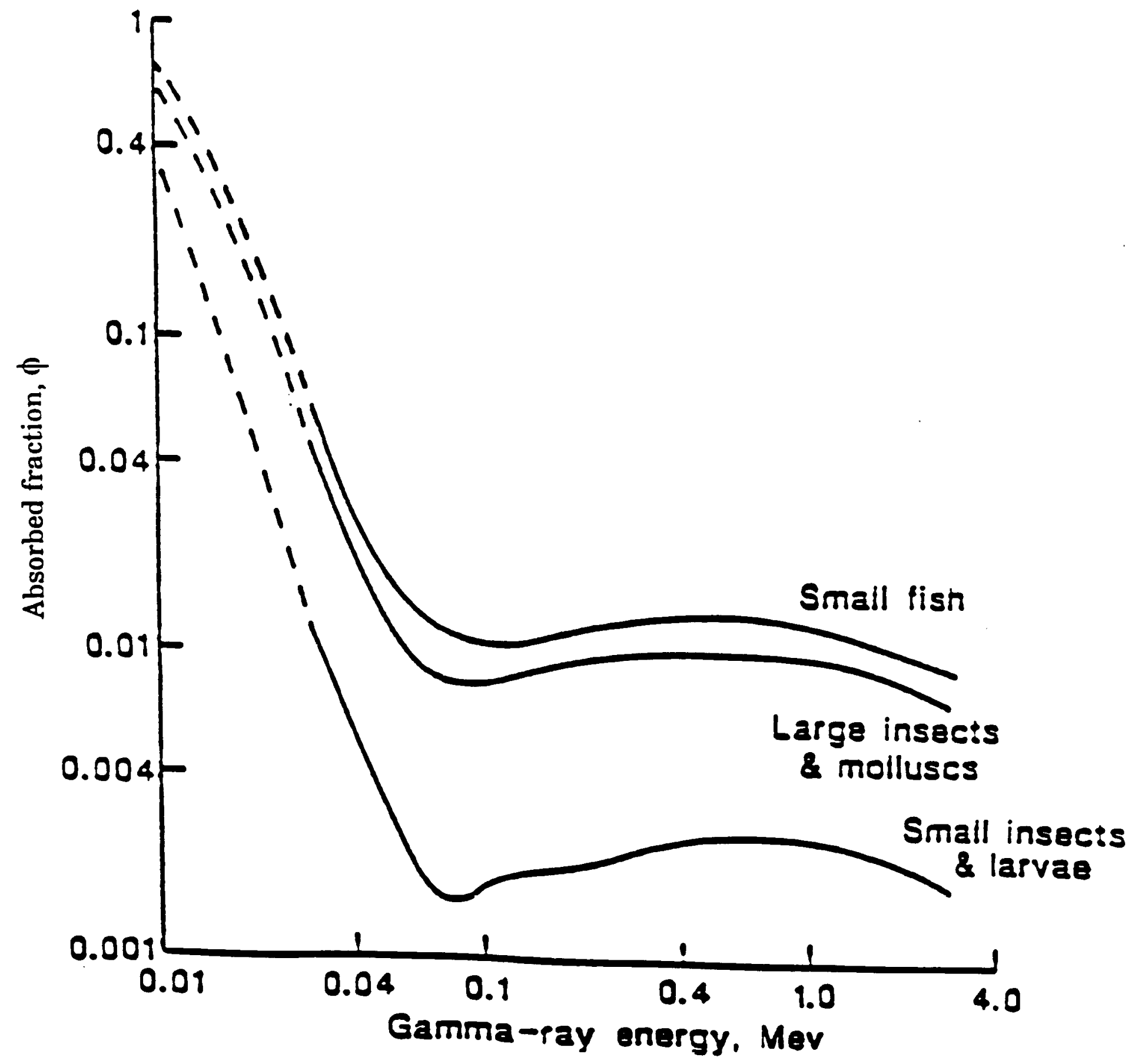

Fig. A.1 Derived absorbed fractions as a function of $\gamma$ ray energy (small fish, large insects and molluscs, and small insects and larvae). 


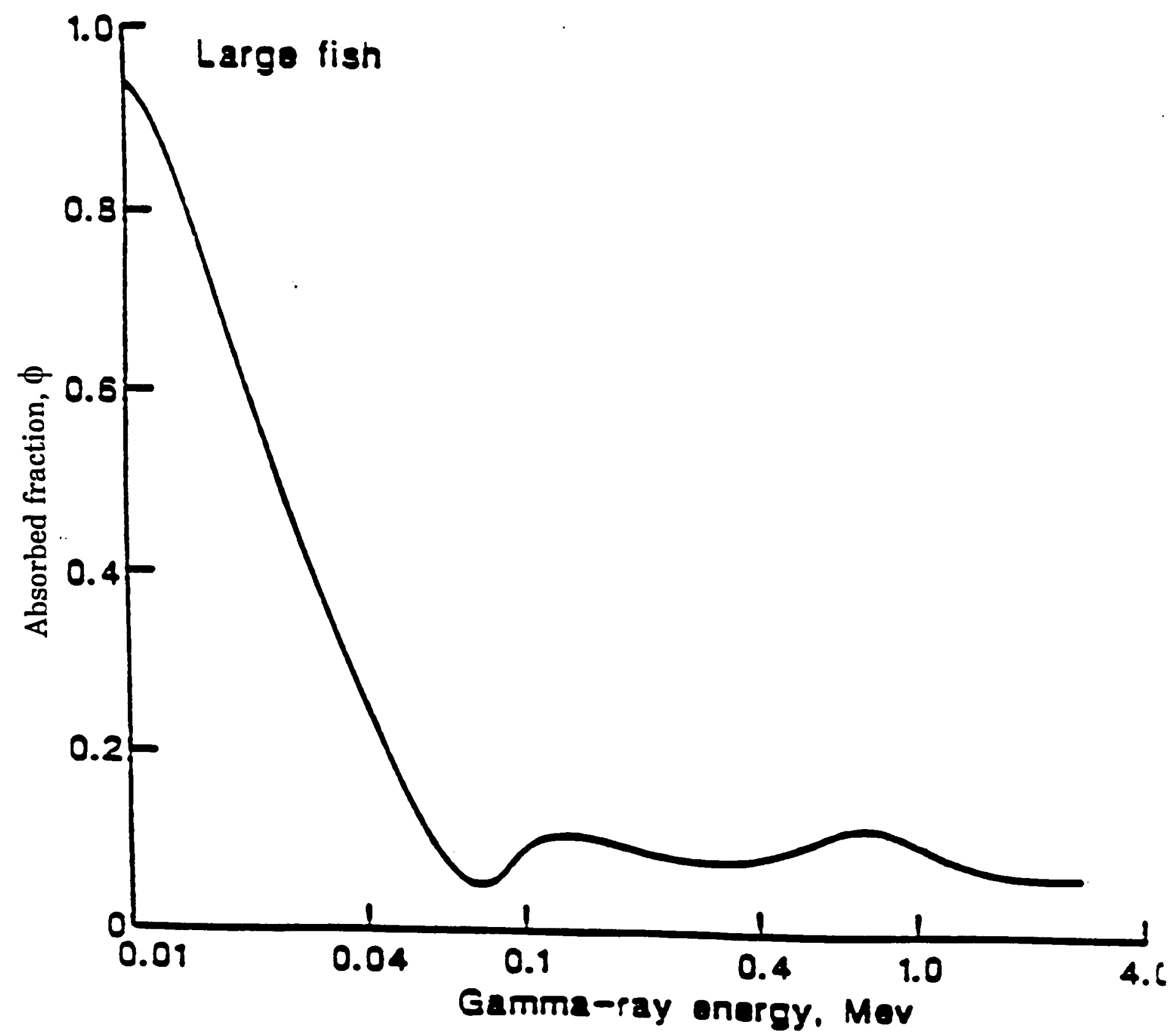

Fig. A.2 Derived absorbed fractions as a function of $\psi$ ray energy (large fish). 


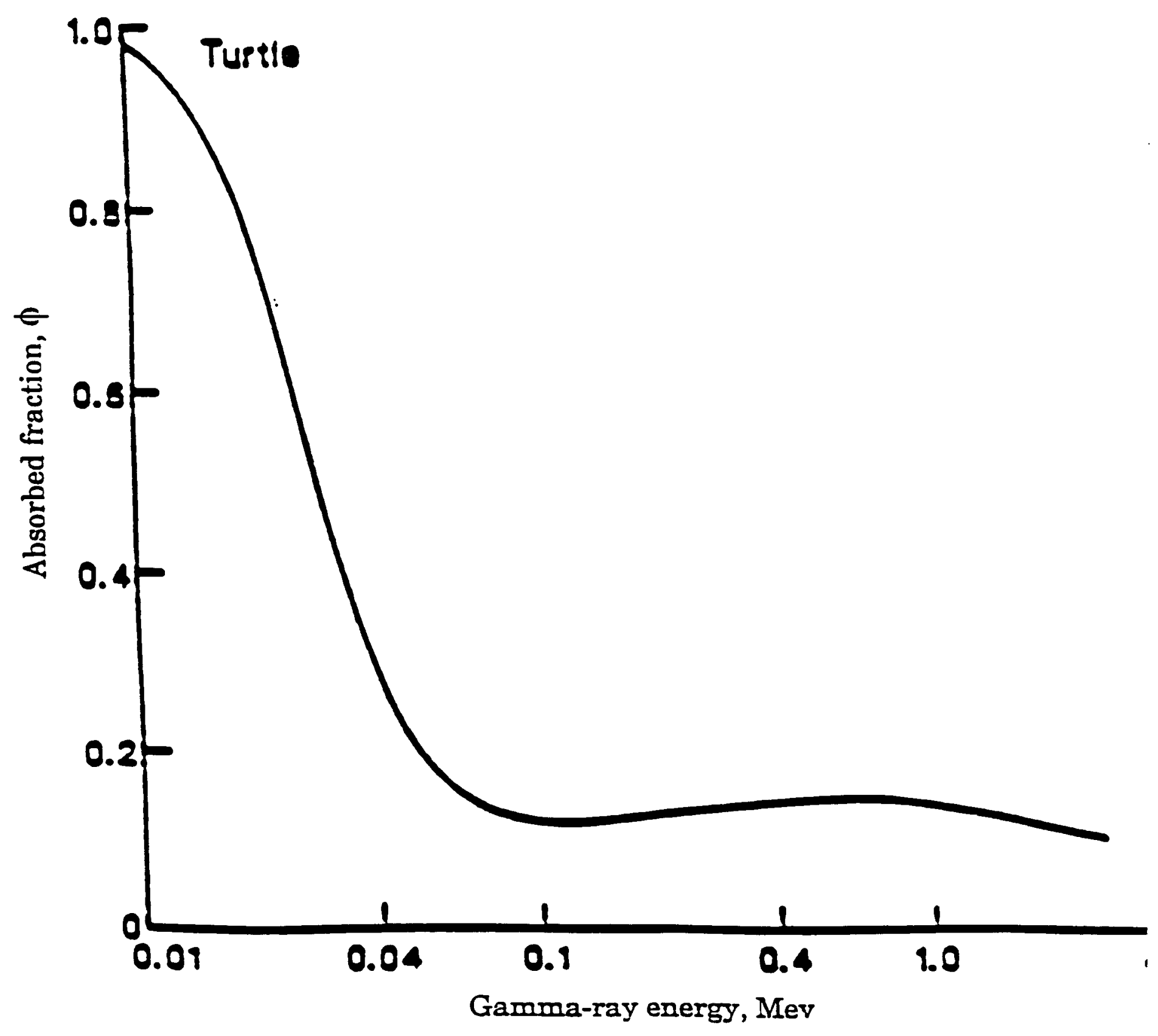

Fig. A.3 Derived absorbed fractions as a function of $\psi$ ray energy (turtle). 


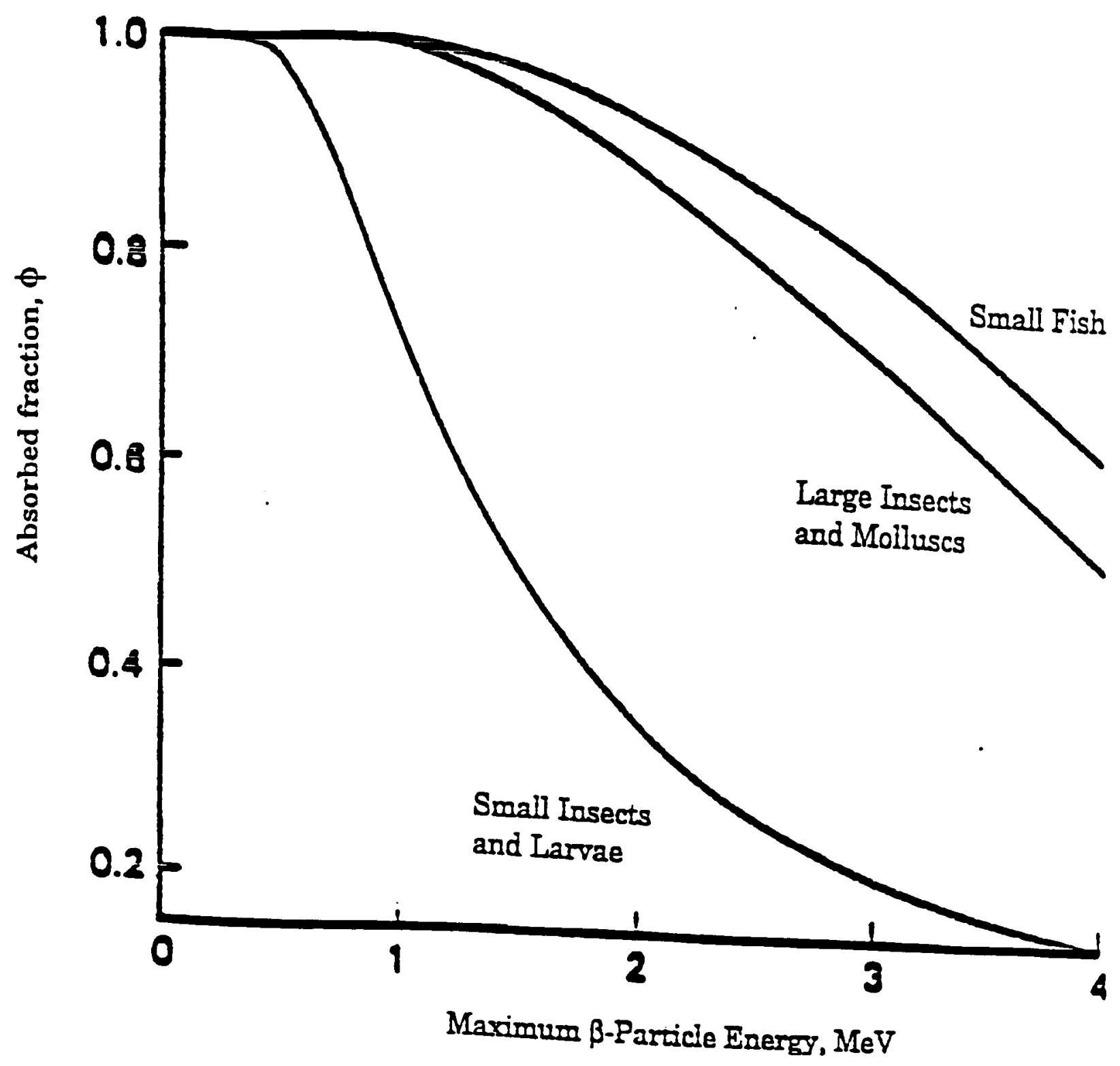

Fig. A.4 Absorbed fraction as a function of $\beta$-particle energy for three small geometries. 
Table A.1. Average energles of selected bela and gamma emilters

\begin{tabular}{|c|c|c|c|c|c|}
\hline Element & $\begin{array}{c}\text { Biological } \\
\text { Concentration } \\
\text { Fector }\end{array}$ & $\begin{array}{c}\text { Radiological } \\
\text { Helf-life }\end{array}$ & $\begin{array}{c}\text { Maximum } \\
\text { bela energy } \\
\text { (MeV) }\end{array}$ & $\begin{array}{c}\text { Averago } \\
\text { beta energy } \\
\text { (MeV) }\end{array}$ & $\begin{array}{c}\text { Averago } \\
\text { gamma energy } \\
(\mathrm{MeV}) \\
\end{array}$ \\
\hline Antimony-125 & 15 & $2.7 y$ & $6.12 \mathrm{E}-01$ & $9.93 \mathrm{E}-02$ & $4.30 \mathrm{E}-01$ \\
\hline Barlum-140 + Lanthanum-140 & 4 & $12.8 \mathrm{~d}, 40.22 \mathrm{~h}$ & $3.21 \mathrm{E}+00$ & 8.44E-01 & $2.49 E+00$ \\
\hline Cerium-141 & 30 & $33 d$ & $5.80 E \cdot 01$ & $1.70 \mathrm{E}-01$ & 7.61E.02 \\
\hline Cerium-144 + Praseodymium-144 & 30 & $284 \mathrm{~d} .17 .3 \mathrm{~m}$ & $3.30 E+00$ & $1.30 E+00$ & 5.25E-02 \\
\hline Cesium-134 & 30 & $2.06 y$ & $1.45 E+00$ & $1.63 E-01$ & $1.55 E+00$ \\
\hline Cesium-137 + Barium-137m & 2000 & $30 \mathrm{y} .2 .6 \mathrm{~min}$ & $1.17 E+00$ & $2.52 E \cdot 01$ & $5.96 \mathrm{E}-01$ \\
\hline Chromlum-51 & -. & $27.8 \mathrm{~d}$ & -. & $3.86 \mathrm{E} \cdot 03$ & $3.26 \mathrm{E}-02$ \\
\hline Coball-60 & 300 & $5.26 y$ & $1.48 \mathrm{E}+00$ & $9.65 E-02$ & $2.50 E+00$ \\
\hline Europlum-154 & 50 & $16 y$ & $1.85 E+00$ & $2.88 E-01$ & $1.22 E+00$ \\
\hline Europium-155 & 50 & $1.81 \mathrm{y}$ & $2.47 E-01$ & $6.26 E-02$ & $6.05 E-02$ \\
\hline Hydrogen-3 & 1 & $12.3 \mathrm{y}$ & $1.80 \mathrm{E} \cdot 02$ & $5.68 \mathrm{E} \cdot 03$ & -. \\
\hline lodine-131 & 40 & $8.05 d$ & 8.10E-01 & $1.90 \mathrm{E}-01$ & $3.80 \mathrm{E}-01$ \\
\hline Niobium-95 & 30 & $35 d$ & $9.30 \mathrm{E}-01$ & $4.40 E \cdot 02$ & $7.66 E-01$ \\
\hline Phosphorus-32 & -. & $14.3 \mathrm{~d}$ & $1.71 E+00$ & $6.95 E-01$ & $\cdots$ \\
\hline Polassium-40 & 10000 & $1.26 E+09 y$ & $1.32 E+00$ & 5.23E-01 & $1.56 \mathrm{E}-01$ \\
\hline Ruthenium-103 & 10 & $39.6 \mathrm{~d}$ & $7.10 \mathrm{E}-01$ & $7.45 \mathrm{E} \cdot 02$ & $4.68 E-01$ \\
\hline Ruthenium-106 + Rhodlum-106 & 10 & $367 \mathrm{~d}, 30 \mathrm{~s}$ & $3.58 E+00$ & $1.42 E+00$ & 2.01E-01 \\
\hline Sodium-24 & $-\cdot$ & $15.0 \mathrm{~h}$ & 4.17E+00 & 5.53E-01 & $4.12 E+00$ \\
\hline Strontium-90 + Yitrium-90 & 60 & 28.1 y. $64 \mathrm{~h}$ & $2.79 E+00$ & $1.13 E+00$ & 1.69E-06 \\
\hline Technetium-99 & 20 & $2.12 E+05 \gamma$ & 2.95E-01 & $1.01 E \cdot 01$ & -. \\
\hline Uranium-237 & 10 & $6.75 d$ & $2.48 E+00$ & $1.94 E-01$ & 1.42E-01 \\
\hline Zinc-65 & $-\cdot$ & $245 d$ & -- & $6.87 E-03$ & 5.84E-01 \\
\hline Zirconium-95 & 300 & $65 d$ & $1.13 E+00$ & $1.16 \mathrm{E}-01$ & 7.39E-01 \\
\hline
\end{tabular}

-The biological concentration factor (BCF) is the ratio of the concentration of the contaminant in Ireshwater fish to the concentration in water a! steady-state conditions. Most BCFs were taken Irom IAEA Report No. 57 (1982)

"Generic Models and Parameters for Assessing the Environmental Transler of Padionuclides Irom Routine Releases".

All average beta and gamma energies were obtained Irom ICAP Report No. 38 . Radiations that conlribute less than $0.1 \%$ of the energy per transformation are omitled. Average Bela Energies $=$ beta particles, conversion electrons, and Auger radiallons, Including those for short-lived progeny. Average Gamma Energies = x-rays, gamma-rays, and photon radiations, including those lor short-lived progeny. 
Table A.2. Average energles of selected alpha emilters Including those of naturally occurring alpha decay serles

\begin{tabular}{|c|c|c|c|c|c|c|}
\hline Element & $\begin{array}{c}\text { Blological } \\
\text { Concentration } \\
\text { Factor }\end{array}$ & $\begin{array}{c}\text { Radlological } \\
\text { Half-life }\end{array}$ & $\begin{array}{c}\text { Average alpha } \\
\text { alpha recoll } \\
(\mathrm{MeV})\end{array}$ & $\begin{array}{c}\text { Maximum beta } \\
\text { energy^ } \\
(\mathrm{MeV})\end{array}$ & $\begin{array}{c}\text { Average } \\
\text { beta energy } \\
(\mathrm{MeV})\end{array}$ & $\begin{array}{c}\text { Average } \\
\text { gamma energy } \\
(\mathrm{MeV})\end{array}$ \\
\hline Plutonium-239 & 30 & $2.41 E+04 y$ & $5.23 E+00$ & & $6.65 \mathrm{E}-03$ & $7.96 \mathrm{E}-04$ \\
\hline Plutonlum-240 & 30 & $6.54 E+04 y$ & $5.24 E+00$ & & $1.06 E-02$ & $1.73 E-03$ \\
\hline \multicolumn{7}{|l|}{ Thorium Series } \\
\hline Thorlum-232 & 100 & $1.41 E+10 y$ & $4.07 E+00$ & & $1.25 \mathrm{E}-02$ & $1.33 E-03$ \\
\hline Radium-228 & 50 & $5.75 y$ &.- & & 1.69E-02 & $4.14 E \cdot 09$ \\
\hline Actinlum-228 & & $6.13 h$ & -. & & $4.60 \mathrm{E}-01$ & 9.30E-01 \\
\hline Thorlum-228 & 100 & $1.91 E+03 y$ & $5.49 E+00$ & & 2.05E-02 & $3.30 \mathrm{E}-03$ \\
\hline Radium-224 & 50 & $3.64 d$ & $5.78 E+00$ & & .. & .. \\
\hline Padon-220 & & $55 \mathrm{~s}$ & $6.40 E+00$ & & 8.19E.06 & $3.85 E-04$ \\
\hline Polonium-216 & 50 & $0.15 \mathrm{~s}$ & $6.91 E+00$ & & $1.61 \mathrm{E}-07$ & $1.69 \mathrm{E}-05$ \\
\hline Lead-212 & 300 & $10.64 \mathrm{~h}$ & .- & & $1.75 E-01$ & $1.48 E-01$ \\
\hline Bismuth-212 & 10 & $60.6 \mathrm{~m}$ & $2.22 E+00$ & 5.80E-01 & $4.69 \mathrm{E}-01$ & $1.85 E-01$ \\
\hline Polonlum-212 (64\% yield) & 50 & $305 \mu \mathrm{s}$ & $8.95 E+00$ & $2.25 E+00$ & -- & .. \\
\hline \multicolumn{7}{|l|}{ Neptunium Series } \\
\hline Americum-241 & 30 & $458 y$ & $5.57 E+00$ & & 5.19E-02 & $3.24 E-02$ \\
\hline Neplunium-237 & 30 & $2.14 E+06 y$ & $4.84 E+00$ & & $6.85 E-02$ & $3.43 E .02$ \\
\hline Protactinium-233 & 10 & $27.0 d$ & -. & & $1.95 E-01$ & 2.03E-01 \\
\hline Uranium-233 & 10 & $1.59 E+05 y$ & $4.89 E+00$ & & $6.08 \mathrm{E}-03$ & $1.31 \mathrm{E}-03$ \\
\hline Thorium-229 & 100 & $7.34 E+03 y$ & $4.95 E+00$ & & $1.14 E \cdot 01$ & $9.54 E-02$ \\
\hline Aadlum-225 & 50 & $.14 .8 \mathrm{~d}$ & $-\cdot$ & & $9.48 E-05$ & 1.37E-02 \\
\hline Aclinium-225 & & $10.0 \mathrm{~d}$ & $5.86 \mathrm{E}+00$ & & $2.17 \mathrm{E}-02$ & $1.79 E-02$ \\
\hline Francium-221 & & $4.8 \mathrm{~m}$ & $6.41 E+00$ & & $9.81 E-03$ & $3.10 \mathrm{E}-02$ \\
\hline Astalline-217 & & $0.032 \mathrm{~s}$ & $7.19 E+00$ & & $3.66 \mathrm{E}-05$ & $3.08 E-04$ \\
\hline Bismuth-213 & 10 & $47 m$ & $1.29 E \cdot 01$ & $1.39 E+00$ & $4.40 \mathrm{E}-01$ & $1.33 \mathrm{E}-01$ \\
\hline Polonium-213 & 50 & $4.2 \mu \mathrm{s}$ & $8.54 E+00$ & & -. & .. \\
\hline Lead-209 & 300 & $3.3 \mathrm{~h}$ & .. & $6.35 \mathrm{E}-01$ & $1.98 \mathrm{E}-01$ & -. \\
\hline
\end{tabular}


Table A.2 (continued)

\begin{tabular}{|c|c|c|c|c|c|c|}
\hline Element & $\begin{array}{c}\text { Blological } \\
\text { Concentration } \\
\text { Factor }\end{array}$ & $\begin{array}{c}\text { Radiological } \\
\text { Malf-life }\end{array}$ & $\begin{array}{c}\text { Average alpha } \\
\text { alpha recoll } \\
(\mathrm{MeV})\end{array}$ & $\begin{array}{c}\text { Maximum beta } \\
\text { energy^ } \\
(\text { MeV) }\end{array}$ & $\begin{array}{c}\begin{array}{c}\text { Average } \\
\text { beta energy } \\
(\mathrm{MeV})\end{array} \\
\end{array}$ & $\begin{array}{c}\text { Average } \\
\text { gamma energy } \\
\text { (MeV) }\end{array}$ \\
\hline \multicolumn{7}{|l|}{ Uranium Series } \\
\hline Uranlum-238 & 10 & $4.51 E+09 y$ & $4.26 E+00$ & & $1.00 E-02$ & $1.36 \mathrm{E} \cdot 03$ \\
\hline Thorlum-234 & 100 & $24.1 \mathrm{~d}$ & -. & & 5.92E.02 & $9.34 E-03$ \\
\hline Protacilnium-234m & 10 & $1.17 \mathrm{~m}$ & .. & $2.29 E+00$ & $8.20 E-01$ & $1.13 E \cdot 02$ \\
\hline Uranium-234 & 10 & $2.47 E+05 y$ & $4.84 E+00$ & & 1.32E-02 & $1.73 E-03$ \\
\hline Thorium-230 & 100 & $7.7 E+04 y$ & $4.74 E+00$ & & $1.46 \mathrm{E}-02$ & $1.55 E-03$ \\
\hline Radium-226 & 50 & $1.62 E+03 y$ & $4.86 E+00$ & & $3.59 E-03$ & $6.47 E-03$ \\
\hline Radon-222 & & $3.823 \mathrm{~d}$ & $5.59 E+00$ & & 1.09E.05 & $3.98 E-04$ \\
\hline Polonium-218 & 50 & $3.05 \mathrm{~m}$ & $6.11 E+00$ & & $1.42 E-05$ & $9.12 E-06$ \\
\hline Lead-214 & 300 & $26.8 \mathrm{~m}$ & .. & $6.70 \mathrm{E}-01$ & $2.91 E-01$ & $2.48 \mathrm{E} \cdot 01$ \\
\hline Astatine-218 (.02\% yleld) & & $2 s$ & $6.82 E+00$ & & $4.00 \mathrm{E}-02$ & $6.72 \mathrm{E} \cdot 03$ \\
\hline Bismuth-214 & 10 & $19.7 \mathrm{~m}$ & .. & $3.26 E+00$ & $6.48 E \cdot 01$ & $1.46 \mathrm{E}+00$ \\
\hline Polonium-214 & 50 & $164 \mu \mathrm{s}$ & $7.83 E+00$ & & $8.19 E \cdot 07$ & 8.33E-05 \\
\hline Lead-210 & 300 & $22.3 y$ & -. & & $3.80 E \cdot 02$ & $4.81 E-03$ \\
\hline Blsmuth-210 & 10 & $5.01 \mathrm{~d}$ & $\cdots$ & $1.16 E+00$ & 3.89E-01 & -. \\
\hline Polonium-210 & 50 & $138.4 \mathrm{~d}$ & $5.40 E+00$ & & $8.18 E-08$ & $8.50 E-06$ \\
\hline \multicolumn{7}{|l|}{ Actinium Series } \\
\hline Uranium-235 & 10 & $7.04+08 y$ & $4.47 E+00$ & & $4.80 \mathrm{E} \cdot 02$ & $1.54 E-01$ \\
\hline Thorium-231 & 100 & $25.5 \mathrm{~h}$ & -. & & $1.63 E-01$ & 2.55E-02 \\
\hline Protactinium-231 & 10 & $328 E+04 y$ & $5.04 E+00$ & & $6.28 \mathrm{E} \cdot 02$ & $4.76 E-02$ \\
\hline Actinium-227 & & $21.77 y$ & $6.90 E-02$ & & $1.56 \mathrm{E} \cdot 02$ & 2.31E-04 \\
\hline Thorlum-227 & 100 & $18.7 \mathrm{~d}$ & $5.95 E+00$ & & 4.57E-02 & 1.06E.01 \\
\hline Padlum-223 & 50 & $11.43 \mathrm{~d}$ & $5.75 E+00$ & & $7.46 E .02$ & $1.33 E .01$ \\
\hline Padon-219 & & $4.0 \mathrm{~s}$ & $6.88 E+00$ & & $6.30 E \cdot 03$ & 5.58E.02 \\
\hline Polonium-215 & 50 & $1.78 \mathrm{~ms}$ & $7.52 E+00$ & & $6.30 \mathrm{E} \cdot 06$ & $1.76 E-04$ \\
\hline Lead-211 & 300 & $36.1 \mathrm{~m}$ & .. & $1.36 E+00$ & 4.54E-01 & $5.03 E-02$ \\
\hline Bismuth-211 & 10 & $2.15 \mathrm{~m}$ & $6.68 E+00$ & & & \\
\hline Thallium-207 & 10000 & $4.79 \mathrm{~m}$ & .. & $1.52 E+00$ & $4.93 E-01$ & $2.21 \mathrm{E} \cdot 03$ \\
\hline
\end{tabular}




\section{Table A.2 (lootnotes)}

- The biological concentration lactor (BCF) Is the ratio of the concentration of the contaminani in freshwater fish to the concentration in water at steady-state conditions. Most BCFs were taken trom IAEA Report No. 57 (1982)

"Generic Models and Parameters lor Assessing the Environmental Transter of Radionuclides lrom Routine Releases".

^ Only maximum beta energies $>0.5 \mathrm{MeV}$ are listed.

All average energles were oblained from ICAP Report No. 38. Radiations that contribute less

than $\mathbf{0 . 1 \%}$ of the energy per translormation are omitted. Average Beta Energies $=$ beta particles, conversion electrons, and Auger radiations, Including those lor short-lived progeny. Average Gamma Energles $=x$-rays, gamma-rays, and photon radiations, including those for short-lived progeny. 
Table A.3 Reproductive effects in fish and invertebrates in natural populations exposed to chronic irradiation.

Organism and life stage exposed

Fish

Gambusia affinis (mosquitofish)

Rutilus rutilus

all life stages

(Roach)
Exposure regime

White Oak Lake

Oak Ridge, TN

contaminated since

1943,1960 dose rate

$\geq 10$ mGy d $\mathrm{d}^{-1}$ falling

to $3.5,1.8$ and $0.6 \mathrm{~m}$

Gy d-1 1965, 1971, 1973,

and 1975 , respectively

Ural Lakes (USSR)

contaminated in

the 1950s; early

1970 s dose rate

7-15 mGy d-1

White Oak Lake

$6.5 \mathrm{mGy} \mathrm{d}^{-1}$
Observation

Greater brood size and embryo mortality in fish

Lower fecundity and delay in spawning
Reference

Blaylock 1969;

Trabalka and

Allen 1977;

Blaylock and

Frank 1980
Voronina et al. 1974; Peshkov et al. 1978

\section{Invertebrates}

Physa

heterstropha

all stages

(pond snail)

Egg-capsule production reduced, but with more eggs per capsule, production rate comparable to to controls 
Table A.4 Reproductive effects in fish exposed to chronic irradiation under laboratory conditions

\begin{tabular}{|c|c|c|c|}
\hline $\begin{array}{l}\text { Organism and life } \\
\text { stage exposed }\end{array}$ & Exposure regime & Observation & Reference \\
\hline $\begin{array}{l}\text { Fish } \\
\text { Oncorhynchus } \\
\text { tschawytscha } \\
\text { embryos (chinook } \\
\text { salmon) }\end{array}$ & $\begin{array}{l}5.0-475 \mathrm{mGy} \mathrm{d}^{-1} \\
\text { for } 80 \mathrm{~d}\end{array}$ & $\begin{array}{l}\text { Gonadal } \\
\text { development of } \\
\text { smolts was } \\
\text { retarded at } \geq 95 \\
\text { mGy d } d^{-1}\end{array}$ & $\begin{array}{l}\text { Bonham and } \\
\text { Donaldson } 1972\end{array}$ \\
\hline $\begin{array}{l}\text { Poecilia reticulata } \\
0-3 \text {-d neonates to } \\
\text { adults }\end{array}$ & $\begin{array}{l}\text { Tritiated water } \\
100-410 \mathrm{mGy} \mathrm{d}^{-1} \\
\text { for } 17 \mathrm{~d}\end{array}$ & $\begin{array}{l}\text { Male courtship } \\
\text { activity reduced }\end{array}$ & Erickson 1973 \\
\hline $\begin{array}{l}\text { Poecilia reticulata } \\
0-3-d \text { neonates to } \\
\text { adults }\end{array}$ & 40.8-305 mGy d-1 & $\begin{array}{l}\text { Infertile at } 40.8 \\
\text { and } 96 \text { mGy } \mathrm{d}^{-1} \\
\text { but fecundity } \\
\text { unaffected }\end{array}$ & $\begin{array}{l}\text { Purdom and } \\
\text { Woodhead } 1973\end{array}$ \\
\hline $\begin{array}{l}\text { Poecilia reticulata } \\
0-3 \text {-d neonates to } \\
\text { adults }\end{array}$ & $\begin{array}{l}40.8-305 \mathrm{mGy} \mathrm{d}-1 \\
\text { up to } 988 \mathrm{~d}\end{array}$ & $\begin{array}{l}\text { Fecundity } \\
\text { reduced to } 57,52 \\
\text { and } 3.5 \% \text { of } \\
\text { controls at } 40.8 \text {, } \\
96 \text {, and } 305 \text { mGy } \\
d^{-1} \text {, respectively; } \\
\text { smaller brood } \\
\text { size all doses }\end{array}$ & Woodhead 1977 \\
\hline $\begin{array}{l}\text { Oryzias Latipes } \\
\text { adult males } \\
\text { (medaka) }\end{array}$ & $\begin{array}{l}12-800 \mathrm{mGy} \mathrm{d} \mathrm{d}^{-1} \\
\text { for } 60-120 \mathrm{~d}\end{array}$ & $\begin{array}{l}\text { Dose rates } 265 \\
\text { mGy } d^{-1} \text { for } 60 \mathrm{~d} \\
\text { increased sterility }\end{array}$ & $\begin{array}{l}\text { Hyodo-Taguchi } \\
1980\end{array}$ \\
\hline $\begin{array}{l}\text { Ameca splendes } \\
\text { young adults }\end{array}$ & $\begin{array}{l}185 \mathrm{mGy} \mathrm{d}-1 \\
\text { up to } 244 \mathrm{~d}^{-1}\end{array}$ & $\begin{array}{l}\text { Complete sterility } \\
\text { after } 190 \mathrm{~d}\end{array}$ & $\begin{array}{l}\text { Rackham and } \\
\text { Woodhead } 1984\end{array}$ \\
\hline
\end{tabular}


Table A.5 Reproductive effects in invertebrates exposed to chronic gamma irradiation from a ${ }^{60} \mathrm{Co}$ source under laboratory conditions

\begin{tabular}{|c|c|c|c|}
\hline $\begin{array}{l}\text { Organism and life } \\
\text { stage exposed }\end{array}$ & Exposure regime & Observation & Reference \\
\hline $\begin{array}{l}\text { Dapinia pulex } \\
\text { all life stages } \\
\text { (cladoceran) }\end{array}$ & $\begin{array}{l}217-721 \mathrm{mGy} \mathrm{h}-1 \\
\text { for } 19 \mathrm{~h} \mathrm{~d}^{-1} \\
\text { for } 20 \text { to } 35 \mathrm{~d}\end{array}$ & $\begin{array}{l}\text { Decreased birth } \\
\text { rate at doses } \\
\geq 4,610 \mathrm{mGy} \mathrm{d}^{-1}\end{array}$ & Marsnall 1962 \\
\hline $\begin{array}{l}\text { Physa } \\
\text { Heterostropha } \\
\text { adult (pond snail) }\end{array}$ & $\begin{array}{l}240-6000 \mathrm{mGy} \mathrm{d}-1 \\
\text { for } 168 \mathrm{~d}\end{array}$ & $\begin{array}{l}\text { Egg and egg- } \\
\text { capsule production } \\
\text { reduced } \\
\text { progressively } \\
\text { over dose rates } \\
480-6,000 \text { mGy d-1 } \\
25^{\circ} \mathrm{C} \text { temperature }\end{array}$ & $\begin{array}{l}\text { Cooley and } \\
\text { Miller } 1971\end{array}$ \\
\hline $\begin{array}{l}\text { Physa } \\
\text { heterostsropha } \\
\text { adult (pond snail) }\end{array}$ & $\begin{array}{l}240-1200 \mathrm{mGy} \mathrm{d}-1 \\
\text { for } 98 \mathrm{~d}\end{array}$ & $\begin{array}{l}\text { Egg production } \\
\text { and egg-capsule } \\
\text { reduced } \\
\text { progressively } \\
\text { over dose range at } \\
25^{\circ} \mathrm{C} \text { but only at } 1200 \\
\text { mGy d-1 at } 15^{\circ} \mathrm{C}\end{array}$ & Cooley 1973 \\
\hline
\end{tabular}


Table A.6 Physiological and histological changes in fish and invertebrates exposed to chronic irradiation under laboratory conditions

Organism and life stage exposed

Fish

Salmo gairdnerii embryos (rainbow trout)

Gambusia affinis adult

(mosquitofish)

Gambusia affinis adult

(mosquito fish)

Poecilia reticulata 0-3-d neonates to adult (guppy)

Oryzia latipes adult males (medaka)

Oryzia latipes adult males

(medaka)

Ameca splendens young adults

Invertebrates

Physa

heterostropha

adult (pond snail)
Exposure regime

2 and $20 \mathrm{mGy} \mathrm{d}^{-1}$

120-130 mGy d-1

360 or 720 mGy d-1

$312-1300 \mathrm{~m} \mathrm{Gd}-1$ $40 \mathrm{~d}$

40.8-305 mGy d-1 up to $974 \mathrm{~d}$

Tritiated water 10-210 mGy d-1 $30 \mathrm{~d}$

12-800 mGy d-1 for $120 \mathrm{~d}$

$185 \mathrm{mGy} \mathrm{d}^{-1}$ up to $244 \mathrm{~d}$

240-1,200 mGy d-1 for $98 \mathrm{~d}$
Observation

Reference

Lowered

antibodies to

Chondrococcus

columaris disease

in juveniles/

yearlings

No hemopoietic damage after $37 \mathrm{~d}$

Cosgrove et al. 1975

mild hemopoietic atrophy in kidney and spleen in some fish after $128 \mathrm{~d}$

Testis atrophy at all dose rates; damage to other tissues not observed

Oogenesis affected at all dose rates; damage appears earlier as dose rate increases

Severe depletion of spermatogonia at $2100 \mathrm{mGy} \mathrm{d}-1$

Cosgrove and Blaylock 1973

Woodhead 1977

Depletion of spermatogonia at $2148 \mathrm{mGy} \mathrm{d}^{-1}$

Spermatogenesis Rackham and more radiosensitive Woodhead 1984 than oogenesis

Hyodo-Taguchi and Egami 1977

Hyodo-Taguchi 1980

Partial atrophy of Cooley $1973 b$ gonads in some snails at $1,200 \mathrm{mGy}$ $\mathrm{d}^{-1}$, but not at lower dose rates 
Appendix B

EXAMPLES SHOWING HOW TO CALCULATE RADIATION DOSE RATES

TO AQUATIC ORGANISMS 


\section{Examples showing how to calculate radiation dose rates to aquatic organisms}

The following examples are included to illustrate how to calculate radiation dose rates to aquatic organisms exposed to low levels of radionuclides in the environment. In all examples, it is assumed that a constant level of radioactivity is present and that the radioactivity in the organism is in equilibrium with that in the environment. The activity levels used in these examples are hypothetical and not intended to represent actual conditions. The energy values $(\mathrm{MeV})$ used in the following examples were obtained from Tables A.1 and A.2. The values for phi $(\Phi)$ were obtained from Figs. A.1 through A.4.

Example 1: $\gamma$ - and $\beta$-dose rates to a large fish

Given: Isotope

Geometry

Activity in organism

Water activity

Sediment activity

$$
{ }^{137} \mathrm{Cs}+{ }^{137 \mathrm{~m}} \mathrm{Ba}
$$

Large fish

$100 \mathrm{~Bq} / \mathrm{kg}$ wet weight

Use BCF to calculate $(\mathrm{Bq} / \mathrm{L})$

$1500 \mathrm{~Bq} / \mathrm{kg}$ wet weight

Equation (1) is used to calculate the internal $\mathrm{Y}$-radiation dose rate as follows:

$$
\mathrm{D}_{\mathrm{\gamma}}=5.76 \times 10^{-4} \mathrm{E}_{\mathrm{\gamma}} \mathrm{n}_{\mathrm{\gamma}} \Phi \mathrm{C}_{\mathrm{o}} \quad \mu \mathrm{Gy} \mathrm{h}^{-1}
$$

substituting the average $\mathrm{Y}$-radiation energy from Table $A .1$ for the $E_{\gamma} n_{\gamma}$ terms and obtaining $\Phi$ from Fig. A.2 gives

$\mathrm{D}_{\mathrm{Y}}=\left(5.76 \times 10^{-4}\right)(0.596)(0.11)(100)$

$\mathrm{D}_{\mathrm{Y}}=3.78 \times 10^{-3} \mu \mathrm{Gy} \mathrm{h} \mathrm{h}^{-1}$ internal $\mathrm{Y}$-radiation.

The activity of ${ }^{137} \mathrm{Cs}$ in the water is calculated from the activity in the fish using a biological concentration factor of 2000 (Table A.1). Equation (2) is used to calculate the external $\mathrm{Y}$-radiation dose rate from water as follows:

$$
D_{\mathrm{v}}=5.76 \times 10^{-4} \mathrm{E}_{\mathrm{v}} \mathrm{n}_{\mathrm{v}}(1-\Phi) \mathrm{C}_{\mathrm{w}} \quad \mu G y \mathrm{~h}^{-1}
$$




$$
\begin{aligned}
& D_{Y}=\left(5.76 \times 10^{-4}\right)(0.596)(1-0.11)(100 / 2000) \\
& D_{Y}=1.53 \times 10-5 \mu G y h^{-1} \text { external } \gamma \text {-radiation from water. }
\end{aligned}
$$

Assuming the fish spends one-half its time near the sediment surface $(R=0.5)$, the external $Y$-radiation dose rate from sediment is calculated as follows:

$$
\begin{aligned}
& D_{\curlyvee}=2.88 \times 10^{-4} E_{\curlyvee} n_{\curlyvee}(1-\Phi) C_{s} R \quad \mu G y h^{-1} \\
& D_{\curlyvee}=\left(2.88 \times 10^{-4}\right)(0.596)(1-0.11)(1500)(0.5) \\
& D_{\curlyvee}=1.15 \times 10^{-1} \mu G y h^{-1} \text { external } \gamma \text {-radiation from sediment. }
\end{aligned}
$$

The total $\mathrm{Y}$-radiation dose rate to the fish in this scenario would be $1.18 \times 10^{-1} \mu \mathrm{Gy} \mathrm{h}^{-1}$ and the major contributor is sediment.

The internal dose rate from the $\beta$-radiation emitted by ${ }^{137} \mathrm{Cs}+{ }^{137 \mathrm{~m}} \mathrm{Ba}$ is calculated as follows:

$$
\mathrm{D}_{\beta}=5.76 \times 10^{-4} \overline{\mathrm{E}}_{\beta} \mathrm{n}_{\beta} \mathrm{C}_{\mathrm{o}} \quad \mu \mathrm{Gy} \mathrm{h} \mathrm{h}^{-1}
$$

using the average energy for all $\beta$-decay spectra from Table A.1, the equation becomes

$$
\begin{aligned}
& D_{\beta}=\left(5.76 \times 10^{-4}\right)(0.252)(100) \\
& D_{\beta}=1.45 \times 10^{-2} \mu G y h^{-1} \text { internal } \beta \text {-radiation. }
\end{aligned}
$$

The $\beta$-dose rate from water and sediment is insignificant to an organism the size of a large fish. The dose rate from the $\mathrm{\gamma}$ - and $\beta$-radiation combined is $1.33 \times 10^{-1 \mu \mathrm{Gy}} \mathrm{h}^{-1}$.

\section{Example 2: $\beta$-dose rate to mollusc}

Given: Isotope

Geometry

Activity in organism

Water activity

Sediment activity
${ }^{90} \mathrm{Sr}+{ }^{90} \mathrm{Y}$

Mollusc

$100 \mathrm{~Bq} / \mathrm{kg}$ wet weight

Use BCF to calculate $(\mathrm{Bq} / \mathrm{L})$

$167 \mathrm{~Bq} / \mathrm{kg}$ wet weight 
The energy of the $\gamma$-radiation from ${ }^{90} \mathrm{Sr}+{ }^{90} \mathrm{Y}$ is insignificant compared to the $\beta$-radiation and can be ignored (Table A.1). The internal $\beta$-dose rate to molluscs is calculated as follows:

$$
D_{\beta}=5.76 \times 10^{-4} \overline{\mathrm{E}}_{\beta} \mathrm{n}_{\beta} \Phi \mathrm{C}_{\mathrm{o}} \quad \mu \mathrm{Gy} \mathrm{h}^{-1}
$$

using the average energy for all $\beta$-decay modes given in Table A.1 for $\mathrm{E}_{\beta} \mathrm{n}_{\beta}$ and $\Phi$ for the $\beta$-particle maximum energy from Fig. A.4, the equation becomes

$$
\begin{aligned}
& D_{\beta}=\left(5.76 \times 10^{-4}\right)(1.13)(0.76)(100) \\
& D_{\beta}=4.95 \times 10^{-2} \mu G y h^{-1} \text { internal } \beta \text {-radiation. }
\end{aligned}
$$

External $\beta$-radiation to molluscs from ${ }^{90} \mathrm{Sr}+{ }^{90} \mathrm{Y}$ in water and sediment would be insignificant because the animal's shell would serve as an effective shield.

\section{Example 3: $\alpha$-dose rate to larvae}

Given: Isotope

Geometry

Activity in organism
${ }^{239} \mathrm{Pu}$

Larva

$100 \mathrm{~Bq} / \mathrm{kg}$ wet weight

The internal $\alpha$-radiation dose rate from ${ }^{239 \mathrm{pu}}$ is calculated as follows:

$$
\begin{aligned}
& D_{\alpha}=5.76 \times 10^{-4} E_{\alpha} n_{\alpha} C_{o} \quad \mu G y h^{-1} \quad \text { Eq. (8) } \\
& D_{\alpha}=\left(5.76 \times 10^{-4}\right)(5.23)(100) \\
& D_{\alpha}=3.01 \times 10^{-1} \mu G y h^{-1} \text { internal } \alpha \text {-radiation. }
\end{aligned}
$$

Only an internal $\alpha$-dose rate from ${ }^{239} \mathrm{Pu}$ is considered because the $\gamma$ - and $\beta$-radiations are very weak and $\alpha$-radiation from external sources would not penetrate the outer covering of the larvae. 


\section{Example 4: dose rates to large fish from isotopes in an $\alpha$-decay chain}

Given: Isotopes

Geometry

Activity in organism

Water activity

Sediment activity
${ }^{226} \mathrm{Ra}$ and short-lived progeny

Large fish

$100 \mathrm{~Bq}$ of ${ }^{226} \mathrm{Ra} / \mathrm{kg}$ wet weight

Use $\mathrm{BCF}$ to calculate $(\mathrm{Bq} / \mathrm{L})$

$1000 \mathrm{~Bq}$ of ${ }^{226} \mathrm{Ra} / \mathrm{kg}$ wet weight

${ }^{226} \mathrm{Ra}$ is a member of the ${ }^{238} \mathrm{U}$ decay chain and it has a series of progeny with short halflives (Table A.2). It is reasonable to assume that because of their short half-lives, these progeny will be present at the same activity level as ${ }^{226} \mathrm{Ra}$. However, ${ }^{226} \mathrm{Ra}$ decays to ${ }^{222} \mathrm{Rn}$ which is a gas with a 3.8 day half-life. ${ }^{222} \mathrm{Rn}$ produced in water or surface sediment would escape to the atmosphere; therefore, the succeeding progeny would not be present in surface sediment or water unless other sources were available. In the example we assume that $30 \%$ of the ${ }^{222} \mathrm{Rn}$ produced within a fish remains in the fish tissue so that the activity level of the succeeding progeny will also be $30 \%$ of the ${ }^{226} \mathrm{Ra}$.

Using average energies from Table A.2 and Equation (8), the internal $\alpha$-dose rates for ${ }^{226} \mathrm{Ra}$ and its short-lived progeny are calculated as follows:

$$
\mathrm{D}_{\alpha}=5.76 \times 10^{-4} \mathrm{E}_{\alpha} \mathrm{n}_{\alpha} \mathrm{C}_{\mathrm{o}} \quad \mu \mathrm{Gy} \mathrm{h}^{-1}
$$

\section{Isotopes}

$$
\begin{aligned}
& { }^{226} \mathrm{Ra} \mathrm{D}_{\alpha}=\left(5.76 \times 10^{-4}\right)(4.86)(100) \\
& =2.80 \times 10^{-1} \quad \mu \mathrm{Gy} \mathrm{h}^{-1} \\
& { }^{222} \operatorname{Rn~} \mathrm{D}_{\alpha}=\left(5.76 \times 10^{-4}\right)(5.59)(100 \times 0.30) \\
& =9.66 \times 10^{-2} \quad \mu \mathrm{Gy} \mathrm{h}^{-1} \\
& { }^{218} \mathrm{Po}_{\alpha}=\left(5.76 \times 10^{-4}\right)(6.11)(100 \times 0.30) \\
& =1.06 \times 10^{-1} \quad \mu \mathrm{Gy} \mathrm{h}^{-1} \\
& { }^{214} \mathrm{~Pb} \mathrm{D}_{\alpha}=\text { no alpha } \\
& { }^{214} \mathrm{Bi} \mathrm{D}_{\alpha}=\text { no alpha } \\
& { }^{214} \mathrm{Po} \mathrm{D}_{\alpha}=\left(5.76 \times 10^{-4}\right)(7.83)(100 \times 0.30) \\
& =1.35 \times 10^{-1} \quad \mu \mathrm{Gy} \mathrm{h}^{-1} \\
& \text { Total internal } \alpha \text {-dose rate } \\
& =6.18 \times 10^{-1} \quad \mu G y h^{-1}
\end{aligned}
$$

The internal dose rate from the $\mathrm{Y}$-emitters with the highest energies is calculated as follows: 


\begin{tabular}{|c|c|c|}
\hline$D_{\gamma}=5.76 \times 10^{-4} E_{\gamma} n_{\gamma} \Phi C_{o}$ & Eq. (1) & \\
\hline${ }^{214} \mathrm{~Pb} \mathrm{D}_{\mathrm{v}}=\left(5.76 \times 10^{-4}\right)(0.248)(0.09)(100 \times 0.30)$ & $=3.86 \times 10^{-4}$ & $\mu \mathrm{Gy} \mathrm{h}^{-1}$ \\
\hline${ }^{214} \mathrm{Bi}_{\mathrm{r}}=\left(5.76 \times 10^{-4}\right)(1.46)(0.07)(100 \times 0.30)$ & $=1.77 \times 10^{-3}$ & $\mu \mathrm{Gy} \mathrm{h}^{-1}$ \\
\hline Total internal $\gamma$-dose rate & $=2.16 \times 10^{-3}$ & $\boldsymbol{\mu G} \mathbf{G} \mathbf{h}^{-1}$ \\
\hline
\end{tabular}

The internal dose rate from the $\beta$-emitters with the highest energies is

$$
\begin{array}{ccc}
\mathrm{D}_{\beta}=5.76 \times 10^{-4} \mathrm{E}_{\beta} \mathrm{n}_{\beta} \Phi \mathrm{C}_{\mathrm{o}} \mu \mathrm{Gy} \mathrm{h} \mathrm{h}^{-1} & \text { Eq. (5) } & \\
{ }^{214} \mathrm{~Pb} \mathrm{D}_{\beta}=\left(5.76 \times 10^{-4}\right)(0.291)(1)(100 \times 0.30) & =5.03 \times 10^{-3} & \mu G y \mathrm{~h}^{-1} \\
{ }^{214} \mathrm{Bi}_{\beta}=\left(5.76 \times 10^{-4}\right)(0.648)(1)(100 \times 0.30) & =1.12 \times 10^{-2} & \mu G y \mathrm{~h}^{-1} \\
\text { Total internal } \beta \text {-dose rate } & =\mathbf{1 . 6 2} \times \mathbf{1 0}^{-2} & \boldsymbol{\mu G y ~ \mathbf { h } ^ { - 1 }}
\end{array}
$$

As shown above, the $\alpha$-dose rate is more than an order of magnitude greater than the dose rates from the $\gamma$ - and $\beta$-emissions. Additionally, the relative biological effectiveness of a radiation is 20 times greater than $\gamma$ - or $\beta$-radiation; consequently, the main concern from ${ }^{226} \mathrm{Ra}$ would be the $\alpha$-dose. 